\title{
Analysis of Education, Training and Job Placement in Improving Employee Performance
}

\author{
Yohanes Susanto $^{1}$, Chamoli Anjana ${ }^{2}$ \\ ${ }^{1}$ Bina Insan University, Indonesia \\ ${ }^{2}$ Dr. Lankapalli Bullayya College, India \\ Correspondent susantoyohanes60@gmail.com ${ }^{1}$
}

\author{
Received : December 8, 2021 \\ Accepted : January 15, 2022 \\ Published : January 31, 2022
}

Citation: Susanto, Y., Anjana, C. (2022). Analysis of Education, Training and Job Placement in Improving Employee Performance. Ilomata International Journal of Management, 3(1),90-103.

https://doi.org/10.52728/ijim.v3i1.401

\begin{abstract}
The purpose of this study is to analyze how much influence the level of education, training, and job placement has on improving employee performance at the Agency for Personnel and Human Resources Development (BKPSDM) Lubuklinggau City, South Sumatra, Indonesia with a population of 70 respondents who are employees of the BKPSDM and elements of the Infectorate Lubuklinggau City. This research is quantitative research with statistical analysis using SPSS version 23 with a multiple linear regression approach to test the hypothesis and test the coefficient of determination. The results showed that simultaneously the level of education, training, and job placement had a positive and significant impact on improving employee performance, but partially job placement had a dominant influence on improving employee performance, with work placements that matched the competencies possessed by employees through education and training will affect improving the performance of the employee concerned, it is recommended that the Employment and Human Resources Development Agency of Lubuklinggau City continue to maintain employees who are following their competencies, and continuously develop the level of education and training of employees.
\end{abstract}

Keywords: Education, Training, Job placement and performance

\section{INTRODUCTION}

Human resources are a very important thing in relation to a government agency or organization, because the success or failure of a government institution is influenced by whether or not the human resources are owned, therefore the selection of human resources to fill organizational needs must match the qualifications needed to fill job vacancies at the organization in question (Mandey \& Lengkong, 2015; Tordera et al., 2020). Efforts to develop human resources include education and training for both formal and non-formal educators according to the opinion that education and training are the forerunners of human resource development (Miranto et al., 2019; Zhou, 2021). One of the efforts to improve employee performance is through education and training, while the opinion is that education and training is a theoretical process to improve the 
skills and morals of employees, people who have received education and training tends to work more skillfully than employees (Hasibuan, 2014; Piwowar-Sulej, 2021), who do not receive education and training (Kazakovs et al., 2015; Sutrisno, 2013). Education and knowledge helps employees to understand the knowledge and skills practically and apply it in their work. If an employee is placed according to his expertise, the employee will be more enthusiastic in carrying out tasks that have an impact on increasing the employee's performance (Asadullah et al., 2021; Yuliana et al., 2015). Improving performance it is necessary to increase employee competence through education and training in accordance with their main duties and functions in work (Bisht \& Mahajan, 2021; Situmorang et al., 2020). The level of competence possessed by employees and is appropriate in work placements has an effect on improving performance, while competence according to is an employee's ability to carry out tasks or work on the basis of knowledge and skills (Tamara et al., 2021). Skills possessed, furthermore suggests that employee education and training has an effect on the performance of the employees themselves (Turere, 2013).

Education is an indicator that reflects a person's ability to complete his work (Moses, 2012). Meanwhile training is the development of human resources specifically designed to develop knowledge, skills, competencies, attitudes and behaviors in order to improve employees performance (Wirawan, 2015). Training is a learning process that mainly focuses on gaining knowledge, improving skills, identifying rules or improving attitudes or behavior to improve employee performance (Ahmad \& Manzoor, 2017). Training is a systematic process to improve knowledge and skills attitudes that lead to increased employee performance (Elnaga \& Imran, 2013). Education and training is an effort to develop human resources, especially to develop intellectual abilities and human personality (Gomes, 2013). Education and training is an effort to maintain and improve the professionalism of employees (Sulistiyani \& Rosidah, 2013). The method used by organizations to maintain, and empower public employees in the organization and at the same time is to increase skills of employees which can ultimately improve employee performance (Wicaksono, 2016).

Training is the assignment of a person to a position in accordance with the expertise and skills they have (Mangkunegara, 2017). What about the effect of job placement on employee performance that employee job placement has a positive effect on improving performance (Montolalu et al., 2016). Job placement is the placement of a person into the right job position, this is focused on the suitability and matching between the knowledge and abilities of employees with the characteristics of their work (Mathis \& Jackson, 2016). Furthermore job placement is one of the functions of the employee. The most important thing in human resource management is whether or not a person is in a certain position depends on the work placement, if the placement function is not carried out, it will automatically have a fatal impact on the achievement of organizational goals (Gomes, 2013). Work placement is a process of assigning tasks and jobs to employees who pass the selection to be carried out based on their responsibilities and authority and are able to overcome the risks of their workload (Ardana et al., 2014). Good employee work placements should be maintained so that there are efforts to improve the performance of the employee in question $(\underline{\mathrm{Ald}, 2020})$. Work placement has a relationship with the competencies possessed by employees in an effort to improve performance (Lussy, 2018). There is a relationship in employee job placement with employee satisfaction levels (Devi et al., 2016). In the placement of employees should look at the period of service, rank and class, education and experience of the employee concerned (Silaban \& Rifai, 2017). Work placements 
that are not in accordance with the competence of employees will affect the work stress Mansur et al., 2017; McLarty et al., 2021). While the performance itself according to that performance is the level of achievement of a person or employee in an organization that can increase productivity (Avery et al., 2015; Muvariz, 2019).

The Employment and Human Resources Development Agency of Lubulinggau City has the main task and function of assisting the Mayor in the field of fostering and developing human resources supported by human resources with the level of competence as shown in the table below:

Table 1 BKPSDM Employee Data of Lubuklinggau City Based on Education Level in

$$
2017-2020
$$

\begin{tabular}{llllll}
\hline \multirow{2}{*}{ Years } & \multicolumn{2}{l}{ Level of education } & \multicolumn{2}{l}{ Number of Employees } \\
\cline { 2 - 5 } & Postgraduate & Undergraduate & $\begin{array}{l}\text { Diploma } \\
3\end{array}$ & $\begin{array}{l}\text { High } \\
\text { School }\end{array}$ \\
\hline $\mathbf{2 1 0 7}$ & 19 & 29 & 1 & 9 & 58 \\
\hline $\mathbf{2 0 1 8}$ & 19 & 26 & 1 & 10 & 56 \\
\hline $\mathbf{2 0 1 9}$ & 16 & 23 & 1 & 10 & 50 \\
\hline $\mathbf{2 0 2 0}$ & 16 & 21 & 0 & 10 & 47 \\
\hline
\end{tabular}

Source: BKPSDM of Lubuklinggau City

Table 1 Lubuklinggau City of BKPSDM office employees based on education level between 2017-2020 shows that from 2017 to 2020 the number of employees who have Post graduate, Undergraduate and Diploma 3 education levels has decreased while at the high school education level experienced a static average, the level of education of employees does not affect performance but the level of training affects employee performance improvement.

Table 2. Data for BKPSDM Employees of Lubuklinggau City by Class Level in $2017-2020$

\begin{tabular}{llllll}
\hline \multirow{2}{*}{ Year } & \multicolumn{2}{l}{ Class Level } & \multicolumn{2}{c}{ Number of Employees } \\
\cline { 2 - 6 } & IV & III & II & I & \\
\hline $\mathbf{2 0 1 7}$ & 8 & 43 & 7 & 0 & 58 \\
\hline $\mathbf{2 0 1 8}$ & 9 & 41 & 6 & 0 & 56 \\
\hline $\mathbf{2 0 1 9}$ & 6 & 38 & 6 & 0 & 50 \\
\hline $\mathbf{2 0 2 0}$ & 6 & 35 & 6 & 0 & 47 \\
\hline
\end{tabular}

Source : BKPSDM of Lubuklinggau City

Table 2 shows data for BKPSDM office employees of Lubuklinggau City based on class level between 2017-2020 showing that from 2017 to 220 the number of employees who have class IV, III and II levels has decreased. While at the level of group I there is a vacancy. According to Government Regulation Number 99 of 2000 concerning the rank of Civil Servants, it is stated that for civil servants, it is a position that shows the level of a civil servant in a series of staffing structures and is used as a basis for salary.. 
Analysis of Education, Training and Job Placement in Improving Employee Performance Susanto and Anjana

Table 3. Types of Education and Training followed by BKPSDM Employees of Lubuklinggau City in 2017-2020

\begin{tabular}{cccll}
\hline Year & $\begin{array}{l}\text { Number of } \\
\text { Employees }\end{array}$ & $\begin{array}{l}\text { Number of } \\
\text { Training } \\
\text { Participants }\end{array}$ & Type of training & Place \\
\hline $\mathbf{2 0 1 7}$ & 58 & 2 & PIM IV & Lubuklinggau \\
\hline $\mathbf{2 0 1 8}$ & 56 & 25 & PIM II,III and IV & Lb Linggau and in Palembang \\
\hline $\mathbf{2 0 1 9}$ & 50 & 18 & PIM III and IV & Lubuklinggau \\
\hline $\mathbf{2 0 2 0}$ & 47 & 13 & PIM III and IV & Lubukliggau \\
\hline
\end{tabular}

Source : BKPSD of Lubuklinggau City

Table 3 shows the type of training that BKPSDM employees participated in Lubuklinggau City between 2017-2020 shows that in 2017 of the 58 employees who attended the training, only 2 employees with level IV leadership training were held in Lubuklinggau City. In 2018 of the 56 employees who attended the training, only 25 employees with the type of leadership training at level II, III and IV, in 2019 of the 50 employees who attended the training only 18 employees with the type of leadership training level III and level IV. In 2020, of the 47 employees who participated in the training, only 13 employees with the type of leadership training at level III and level IV were carried out in Lubuklinggau City. Educational competence and work experience within the scope of BKPSM Lubuklinggau City greatly influence in carrying out the duties and positions assigned to each employee. An employee who is placed at the BKPSDM office in Lubuklinggau City as an employee, of course he must have education and work experience first in order to help himself in carrying out the tasks assigned to him.

Table 4. Results Achieved by BKPSDM Employees of Lubuklinggau City in 2017 -2020

\begin{tabular}{llll}
\hline Year & $\begin{array}{l}\text { Number of } \\
\text { Employees }\end{array}$ & $\begin{array}{l}\text { Number of Training } \\
\text { Participants }\end{array}$ & $\begin{array}{l}\text { Results achieved after attending } \\
\text { the Training (\%) }\end{array}$ \\
\hline $\mathbf{2 0 1 7}$ & 58 & 2 & $3,40 \%$ \\
\hline $\mathbf{2 0 1 8}$ & 56 & 25 & $44,64 \%$ \\
\hline $\mathbf{2 0 1 9}$ & 50 & 18 & $36,00 \%$ \\
\hline $\mathbf{2 0 2 0}$ & 47 & 13 & $27,65 \%$ \\
\hline
\end{tabular}

Source: BKPSDM of Lubuklinggau City

Table 4 shows the results achieved by BKPSDM employees in the city of Lubuklinggau between 2017-2020, it shown that the number of employees participating in the training is different. In 2017 of the total 58 employees, only 2 people participated in the training and the results achieved after participating in the training were $3.40 \%$. In 2018 of the 56 employees, only 25 people participated in the training and the results achieved after participating in the training were $44.64 \%$. In 2019 out of 50 employees, only 18 people participated in the training and the results achieved after participating in the training were $36.00 \%$. in the following year in 2020 of the total 47 employees, only 13 people participated in the training and the results achieved after participating in the training also increased, namely $27.65 \%$.

As a regional apparatus that manages personnel, BKPSDM has the task of achieving performance targets in the field of apparatus resource management development. The main 
indicator of the success of the development of human resource management in Indonesia is the Achievement of the Professionalism Index. This is in accordance with the Regulation of the Minister of State Apparatus Empowerment and Bureaucratic Reform of the Republic of Indonesia Number 38 of 2018 concerning the Measurement of the Professionalism Index of the State Civil Apparatus and the Regulation of the State Civil Service Agency Number 8 of 2019 concerning Guidelines for Procedures and Implementation of the Measurement of the Professionalism Index of the State Civil Apparatus. The index indicators are qualification, competence, discipline and performance. The following presents the achievements of the ASN professionalism index in Lubuklinggau City:

Table 5 Level of Achievement of the ASN Professional Index of Lubuklinggau City in 2020

\begin{tabular}{|c|c|c|c|}
\hline No & Professionalism & $\begin{array}{l}\text { ASN Professionalism } \\
\text { Index Achievements }\end{array}$ & $\begin{array}{l}\text { Ideal Achievement of ASN } \\
\text { Professionalism Index }\end{array}$ \\
\hline 1 & Quality & 13,28 & 25,0 \\
\hline 2 & Competence & 10,48 & 40,0 \\
\hline 3 & Discipline & 5,0 & 5,0 \\
\hline 4 & Performance & 25,0 & 30,0 \\
\hline & Total & 53,76 & 100 \\
\hline
\end{tabular}

From these data it appears that the achievement of the State Civil Apparatus (ASN) professionalism index of the Lubuklinggau City Government of 53.76 is still low. Apart from the ASN professionalism index indicator, BKPSDM's performance achievement is also measured by the system merit index. Based on the calculation of the system merit index in the SIPINTER application, the State Civil Apparatus Commission, the achievement of the Lubuklinggau City Government is 192.5. This achievement is included in the low category.

The low performance achievement of BKPSDM is suspected to be caused by the lack of ASN personnel at BKPSDM which can be seen from the results of the Lubuklinggau City BKPSDM Workload analysis, therefore it is necessary to empower civil servants and optimize their placement so that the performance target of BKPSDM of the City is achieved.

Based on the conceptual framework, several research hypotheses were prepared to be tested. The hypothesis is as follows:

1. It is presumed that the level of education held has a positive influence on employee performance at the BKPSDM of Lubuklingau City

2. It is presumed that the training (Diklat) held has a negative effect on employee performance at the BKPSDM of Lubulinggau City

3. It is presumed that the work placements held have a negative effect on the performance of employees at the BKPSDM of Lubulinggau City

4. It is presumed that the level of education, training (Diklat) and work placements that are held together have a negative effect on employee performance at the BKPSDM of Lubulinggau City 


\section{METHOD}

This research method is descriptive associative, descriptive research is the simplest research compared to other research, in research it does nothing to the object under study associative research is research whose purpose is to analyze the relationship between two or more variables (Arikunto, 2013; Hamilton \& Finley, 2020). Sample selection using cluster sampling, namely the sampling technique by selecting from a small unit group, with a sample of 70 people and data collection techniques using questionnaires compiled using a Likert scale with a score of 1 to 5 and to ensure that the instruments used in This research can be trusted, then two tests must be carried out, namely the validity test and the reliability test (Hamilton \& Finley, 2019; $\underline{\text { Sugiyono, }}$ 2019). At the stage of analyzing the data on the influence of Education, Training and Work Placement on Employee Performance, descriptive analysis and inductive analysis were carried out, including normality test, multicollinearity test, heteroscedasticity test and multiple linear regression analysis, for hypothesis testing data used $\mathrm{F}$ test, $\mathrm{t}$-test and coefficient of determination test $\left(\mathrm{R}^{2}\right)$

\section{RESULTS AND DISCUSSION}

\section{Validity and Reliability Test}

Test instrument validity is used to measure whether the questionnaire is valid or not, where a questionnaire is said to be valid if the question or statement is able to reveal something that will be measured by the questionnaire. The validity test criteria is if $r$-count $>\mathrm{r}$-table $(0.312)$ then the instrument/question item is declared valid, on the contrary if r-count $<$ r-table then the question/item is declared invalid, so it must be removed or replaced by the validity test results which can be seen [there is a table below:

Table 6. Test the validity of the variables Education, Training, Job placement and performance

\begin{tabular}{llll}
\hline Variable & Statement & Valid & Item Invalid \\
\hline Education Level & 10 & 10 & 0 \\
Training & 10 & 10 & 0 \\
Job placement & 10 & 10 & 0 \\
Performance & 10 & 10 & 0 \\
\hline
\end{tabular}

Sources processed by researchers 2020

Table 7 Reliability Test of Education, Training, Job Placement and Performance variables

Reliability test is used to test the consistency or stability of the score of a research instrument on the same respondent, and is given at different times. The criteria to determine whether the instrument is reliable or not, namely if the value of Cronbach's Alpha is 0.6, the instrument is declared reliable. On the other hand, if Cronbach's Alpha value is 0.6 then the instrument is declared unreliable. The results of the reliability test can be seen in Table 7 below:

Table 7. Reliability Test Result

\begin{tabular}{lll}
\hline Variable & Cronbach's Alpha & Description \\
\hline Employee competence & .921 & Reliable \\
Work commitment & .979 & Reliable \\
Work motivation & .901 & Reliable \\
Performance & .974 & Reliable \\
\hline
\end{tabular}

Sources processed by Researchers 2020 
From the table above, it can be seen that all questions are valid and reliable, so all questions are included in the next analysis.

\section{Classic assumption test}

The purpose of classical assumption testing is to provide certainty that the regression equation obtained has accuracy in estimation, is unbiased, and is consistent, before conducting regression analysis, the classical assumption test is first carried out, including normality test, linearity test, heteroscedasticity test, and multicolonearity test.

\section{Normality Test}

Normality test to test whether in a regression model, the dependent variable, and the independent variable, or both have a normal distribution or not. A good regression model is to have a normal distribution or close to normal. To detect the normal regression model or not, it can be seen from the Normal P-P Plot. If the data spreads around the diagonal line and follows the direction of the diagonal line, then the regression model fulfills the assumption of normality. If not, or the data is spread far from the diagonal line, then the regression model does not meet the assumption of normality. The results of the normality test can be seen from Figure 1

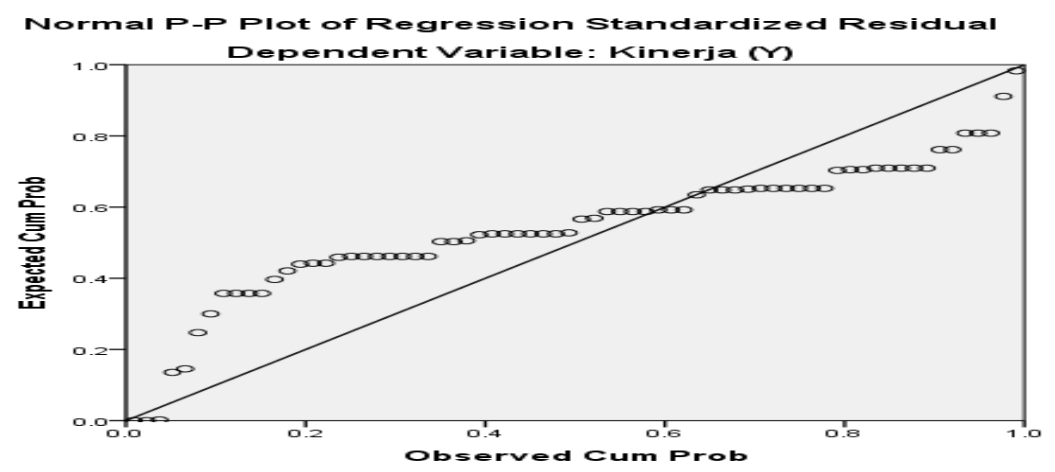

Figure 1. Normal P-P Plot

From Figure 1, it can be seen that the dots spread around the diagonal line and their distribution follows the direction of the diagonal line. So the regression model is feasible to use for predicting performance variables based on input from independent variables.

\section{Linearity Test}

Linearity testing is carried out to find out whether the model being proven is a linear model or not. The result of this linearity test is information on whether the empirical model should be linear, quadratic or cubic. To detect whether the model should use a linear equation or not, it is used by graphical analysis methods and statistical methods. Statistical methods that can be used to perform linearity testing are the Durbin-Watson Test, Ramsey Test, LM Test and MWD Test. The linearity test aims to determine whether two variables have a linear relationship or not significantly. This test is usually used as a prerequisite in correlation analysis or linear regression. Testing on SPSS using the Test for Linearity with a significance level is 0.05 . Two variables are said to have a linear relationship if the significance (Linearity) is less than 0.05 . 
Table 11 Testing the linearity between X1, X2,X3 and Y

\begin{tabular}{ll}
\hline Variable & Significances \\
\hline Linearity Variable X1 & .285 \\
\hline Linearity Variable X2 & .196 \\
\hline Linearity Variable X3 & .317 \\
\hline
\end{tabular}

Source: Primary data, processed. 2021

Based on table 11, the results of linearity testing show that Education (X1) Training (X2) job placement (X3) has a linear relationship with performance (Y). Sig value $<0.05$

\section{Heteroscedasticity Test}

Heteroscedasticity test aims to test whether in the regression model there is an inequality of variance from the residuals of one observation to another observation. If the variance of the residuals from one observation to another observation remains, it is called Homoscedasticity, while if it is different it is called Heteroscedasticity. A good regression model does not have heteroscedasticity problems.

To see whether there is a heteroscedasticity problem, it can be detected by the presence or absence of a certain pattern on the scatter plot graph, if there is a certain pattern, such as dots that form a regular pattern (wavy, widened then narrowed) then heteroscedasticity has occurred. Meanwhile, if there is no clear pattern, and the points spread above and below the number 0 and the $\mathrm{Y}$ axis, then there is no heteroscedasticity. The results of the heteroscedasticity test can be seen in Figure 2

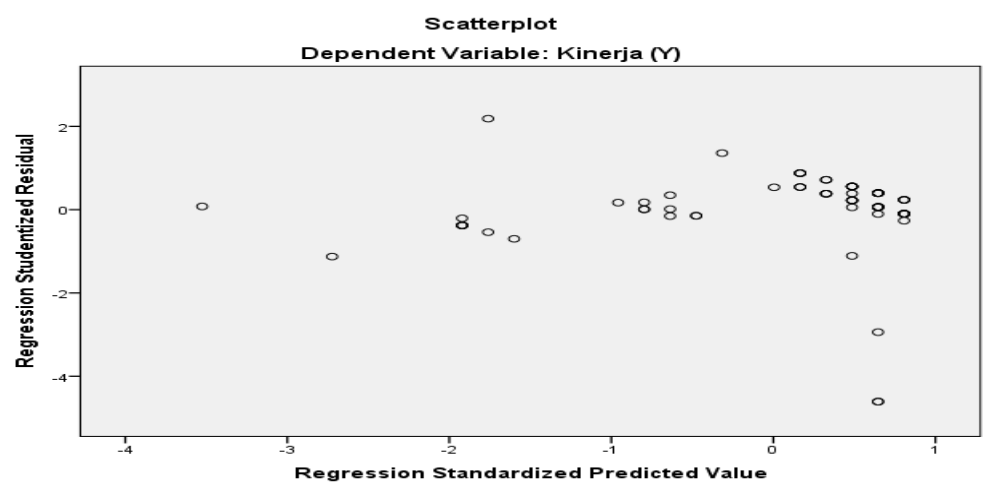

Figure 2. Scatter plot

4. Multicollinearity Test

Multicollinearity testing aims to test whether the regression model found a correlation between the independent variables. A good regression model should not have a correlation between independent variables. A good regression model should not have a correlation between the independent variables. To detect the presence of multicollinearity, it can be seen with the value of VIF (Variance Inflation Factor) and Tolerance. The multicolline-free regression equations are: Having a VIF value not exceeding 10 and having a tolerance number close to 1 . For the results of the multicollinearity test, it can be seen from table 1 below. 
Analysis of Education, Training and Job Placement in Improving Employee Performance Susanto and Anjana

\begin{tabular}{cccc}
\hline \multicolumn{2}{c}{ Table 12 Multicollinearity Test } \\
\hline \multirow{2}{*}{ No } & Variabel & \multicolumn{2}{c}{ Collinearity statistics } \\
\cline { 3 - 4 } & & Tolerance & VIF \\
\hline $\mathbf{1}$ & Education (X1) & .384 & 2.603 \\
\hline $\mathbf{2}$ & Training (X2) & .980 & 1.020 \\
\hline $\mathbf{3}$ & Job placement (X3) & .389 & 2.572 \\
\hline
\end{tabular}

Source: Primary data, processed. (used by year)

Table 12 shows that the tolerance value is close to 1 and the VIF value for the two independent variables does not exceed 10 , so there is no multicollinearity problem.

\section{Multiple Linear Regression Analysis}

In this regression analysis the backward method is used, where in this method in the initial test, all independent variables were included in the test and then removed one by one if they did not meet the $t$ significance value below 0.05 . The resulting output table will show the process/steps when these variables are removed, each row will be equipped with a number indicating the steps/processes carried out. In the discussion of this chapter, it will only be discussed in the last row/last process in each table, this is intended because in each last row is the result of the last test which is a variable that has a significance value of $\mathrm{t}$ below 0.05 .

\section{Hypothesis test: 1}

Hypothesis 1 reads: It is suspected that the level of education held has a positive influence on employee performance at the BKPSDM of Lubuklingau City. The hypothesis is then tested using the $t$ test. The results of these tests are as follows:

Table 13 Hypothesis testing 1

\begin{tabular}{|c|c|c|c|c|c|}
\hline \multirow[t]{3}{*}{ Model } & \multicolumn{2}{|c|}{ Unstandardized } & \multirow{2}{*}{$\begin{array}{l}\text { Standardized } \\
\text { Coefficients }\end{array}$} & \multicolumn{2}{|c|}{$\mathrm{t}$} \\
\hline & Coefficients & & & & ig. \\
\hline & \multirow{2}{*}{\multicolumn{2}{|c|}{$\begin{array}{ll}\text { Std. } \\
\text { Error }\end{array}$}} & Beta & & \\
\hline & & & & & \\
\hline (Constant) & .114 & .737 & & .155 & .877 \\
\hline Education (X1) & .928 & .160 & .576 & 5.816 & .000 \\
\hline
\end{tabular}

Result: 1,995 $\leq$ 5.816, Decision= Rejected $\mathrm{H}_{0}$

Based on the test, the decisions taken are reject $\mathrm{H}_{0}$ so it was concluded that the level of education held had a positive influence on employee performance at the BKPSDM of Lubuklingau City.

\section{Hypothesis test 2}

Hypothesis 2 reads: Presumed education and traing (Diklat) that is held has a negative effect on employee performance at the BKPSDM of Lubulinggau City. The hypothesis is then tested using the $t$ test. The results of these tests are as follows:

Tabel 14 Pengujian hipotesis 2

\begin{tabular}{|c|c|c|c|}
\hline \multirow[t]{2}{*}{ Model } & $\begin{array}{l}\text { Unstandardized } \\
\text { Coefficients }\end{array}$ & $\begin{array}{l}\text { Standardized } \\
\text { Coefficients }\end{array}$ & $\begin{array}{lll} & & S \\
& \text { ig. } & \end{array}$ \\
\hline & B & Beta & \\
\hline
\end{tabular}


Analysis of Education, Training and Job Placement in Improving Employee Performance Susanto and Anjana

\begin{tabular}{lllllllll}
\hline (Constant) & & 4.18 & & .68 & & 6.134 & & $\cdot$ \\
& 6 & & 2 & & & & 000 & \\
\hline Training(X2) & & .041 & & .14 & .034 & .278 & & $\cdot$ \\
& & & 6 & & & & 781 & \\
\hline (Constant) & & 4.37 & & .10 & & 43.082 & & $\cdot$ \\
& 4 & & 2 & & & & 000 & \\
\hline
\end{tabular}

Result: $1,995 \geq 0,278$, Decision= Accepted $\mathrm{H}_{0}$

Based on the test, the decision taken was to accept $\mathrm{H}_{0}$ so it was concluded that it was suspected that the training (Training) held did not have a negative effect on employee performance at the BKPSDM of Lubulinggau City.

\section{Hypothesis test 3}

Hypothesis 3 reads: Presumed that the work placement system organized has a negative effect on employee performance at the BKPSDM of Lubulinggau City. The hypothesis is then tested using the $\mathrm{t}$ test. The results of these tests are as follows:

Table 15 Hypothesis test3

\begin{tabular}{|c|c|c|c|c|c|}
\hline \multirow[t]{2}{*}{ Model } & \multicolumn{2}{|c|}{ Coefficients } & $\begin{array}{l}\text { Standardized } \\
\text { Coefficients }\end{array}$ & $\mathbf{t}$ & \multirow[t]{2}{*}{ ig. } \\
\hline & B & Std. Error & Beta & & \\
\hline (Constant) & .04 & .53 & & .080 & . \\
\hline & 2 & 1 & & & 937 \\
\hline placement & .96 & .11 & .707 & 8.236 & \\
\hline (X3) & 3 & 7 & & & 000 \\
\hline
\end{tabular}

Result: $1,995 \leq 8,236$, Decision $=$ Rejected $\mathrm{H}_{0}$

Based on the test, the decision taken was to reject $\mathrm{H}_{0}$ so it was concluded that the work placements held had a non-positive influence on employee performance at the BKPSDM of Lubulinggau City.

\section{Hypothesis test 4}

Hypothesis 7 reads: Presumed that the level of education, training and work placements that are held together have a positive influence on employee performance at the BKPSDM of Lubulinggau City. The hypothesis is then tested using the F test test. The results of the test are as follows:

Table 14 Hypothesis test 4

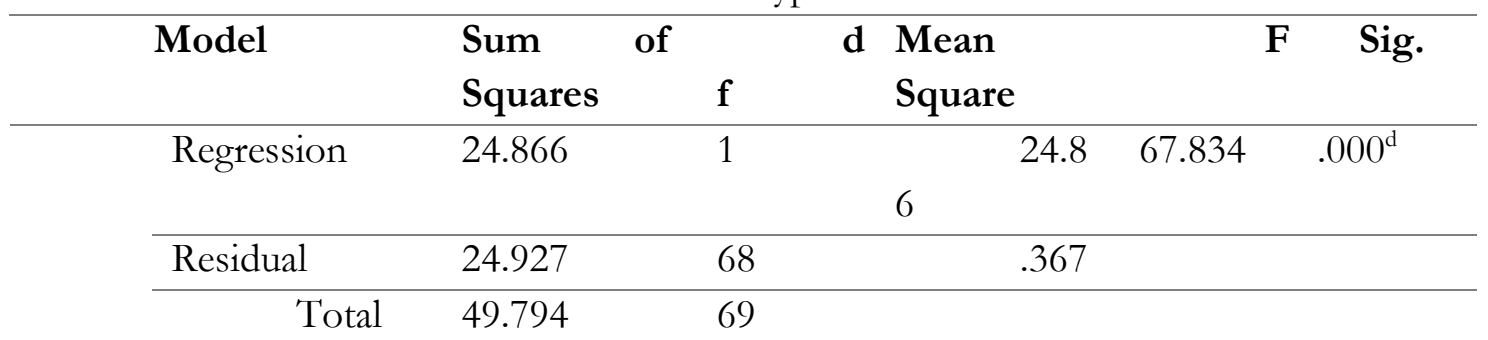

Result: 3,31 $\leq 67,834$, Decision= Rejected $\mathrm{H}_{0}$ 


\section{Result of Analysis of the Coefficient of Determination (Adjusted $\mathbf{R}^{2}$ )}

Table 15. Results of Analysis of the Coefficient of Determination (Adjusted R²)

\begin{tabular}{lcclcc}
\hline \multicolumn{5}{c}{ Model Summary } \\
\hline Model & $\mathrm{R}$ & Square & $\begin{array}{l}\text { Adjusted } \\
\text { Square }\end{array}$ & $\mathrm{R}$ & Std. Error of the Estimate \\
\hline $\mathbf{1}$ & $864^{\mathrm{a}}$ & 746 &, 754 & 1,877 \\
\hline
\end{tabular}

Sources processed by researchers 2020

Based on Table 15, above the $\mathrm{R}^{2}$ ( $\mathrm{R}$ Square) figure is 0.746 or $(74,5 \%)$. This shows that there is strong influence by the education variable, training variable and work placement variable on performance at the Agency for Personnel and Human Resources Development (BKPSDM_ because it is $74,5 \%$. While the remaining $25,5 \%$ is explained or influenced by other variables which are not researched

Based on the test, the decision taken was to reject $\mathrm{H}_{0}$ so it was concluded that the level of education, training and work placements that were held together gave a positive influence on the performance of employees at the BKPSDM of Lubulinggau City.

\section{CONCLUSION}

Based on the results of data processing that has been carried out, it can be concluded that this study proves empirically about

1. Education level has an effect on increasing employee performance at the Agency for Personnel and Human Resources Development of Lubuklinggau City

2. Training has no effect on improving employee performance at the Agency for Personnel and Human Resources Development of Lubuklinggau City

3. Work Placement has an effect on increasing employee performance at the Agency for Personnel and Human Resources Development of Lubuklinggau City.

4. The level of education, training and work placement together to improve the performance of employees at the Employment and Human Resources Development Agency of Lubuklinggau City

Based on the conclusion, the research suggestion is that there must be an effort to increase the level of education at the Agency for Personnel and Human Resources Development of Lubuklinggau City because it affects performance. There should be an increase in training at the Agency for Personnel and Human Resources Development of Lubuklinggau City because it does not affect performance. Maintaining work placement efforts at the Agency for Personnel and Human Resources Development of Lubuklinggau City because it affects performance.

\section{REFERENCES}

Ahmad, I., \& Manzoor, S. R. (2017). Effect of Teamwork, Employee Empowerment and Training on Employee Performance. International Journal of Academic Research in Business and Social Sciences, 7(11). https://doi.org/10.6007/IJARBSS/v7-i11/3472

Aldy, H. L. N. (2020). Pengaruh Penempatan Kerja Terhadap Kinerja Karyawan pada Yayasan 
Hanifa Islamic School. Jurnal Ekonomi Efektif, 2(2). https://doi.org/10.32493/JEE.v2i2.4157

Ardana, I. K., Mujiati, N. W., \& Utama, I. W. M. (2014). Manajemen Sumber Daya Manusia (2nd ed.). Graha Ilmu. https://opac.perpusnas.go.id/DetailOpac.aspx?id=1177812

Arikunto, S. (2013). Prosedur Penelitian: Suatu Pendekatan Praktik (8th ed.). Rineka Cipta. https:/ /opac.perpusnas.go.id/DetailOpac.aspx?id=217760

Asadullah, M. A., Ul Haq, M. Z., Wahba, K., Hashmi, S., Kim, H. (Markham), \& Hwang, J. (2021). Gender differences and employee performance: Evidence from the restaurant industry. Journal of Hospitality and Tourism Management, 48, 248-255. https://doi.org/10.1016/j.jhtm.2021.06.015

Avery, R. E., Smillie, L. D., \& Fife-Schaw, C. R. (2015). Employee achievement orientations and personality as predictors of job satisfaction facets. Personality and Individual Differences, 76, 5661. https://doi.org/10.1016/j.paid.2014.11.037

Bisht, N. S., \& Mahajan, A. (2021). Shared stressors and core self-evaluations: A trait activation perspective on employee performance. Journal of Business Research, 131, 103-111. https://doi.org/10.1016/j.jbusres.2021.03.053

Devi, C. R., Susilo, E. A., \& Ratri, A. M. (2016). Pengaruh Penempatan dan Kepuasan Kerja Terhadap Kinerja Karyawan. Jurnal Bisnis Dan Manajemen Universitas Merdeka Malang, 3(2), 129-141. https://doi.org/https://doi.org/10.26905/jbm.v3i2.416

Elnaga, A., \& Imran, A. (2013). The Effect of Training on Employee Performance. International Journal of Recent Technology and Engineering, 5(4), 137-147. https://www.iiste.org/Journals/index.php/EJBM/article/view/4475

Gomes, F. C. (2013). Manajemen Sumber Daya Manusia (3rd ed.). Andi Publisher. https://library.unismuh.ac.id/opac/detail-opac?id=1383

Hamilton, A. B., \& Finley, E. P. (2019). Qualitative methods in implementation research: An introduction. Psychiatry Research, 280, 112516. https://doi.org/10.1016/j.psychres.2019.112516

Hamilton, A. B., \& Finley, E. P. (2020). Reprint of: Qualitative methods in implementation research: An introduction. Psychiatry Research, 283, 112629. https://doi.org/10.1016/j.psychres.2019.112629

Hasibuan, M. S. P. (2014). Manajemen Sumber Daya Manusia (12th ed.). Bumi Aksara. https://opac.perpusnas.go.id/DetailOpac.aspx?id=576827

Kazakovs, M., Verdina, A., \& Arhipova, I. (2015). Automation of Human Resources Development Planning. Procedia Computer Science, 77, 234-239. https://doi.org/10.1016/j.procs.2015.12.379

Lussy, K. (2018). Pengaruh Penempatan dan Kompetensi Karyawan Terhadap Kinerja Karyawan Pada Perusahaan Daerah Panca Karya Ambon Bagian Transportasi Laut. JURNAL MANEKSI, 7(1), 26. https://doi.org/10.31959/jm.v7i1.88

Mandey, M. A., \& Lengkong, V. P. . (2015). Pengaruh Kompensasi, Gaya Kepemimpinan, dan Lingkungan Kerja Terhadap Kinerja Pegawai (Studi Pada Fakultas Ekonomi dan Bisnis Universitas Sam Ratulangi Manado). Jurnal EMBA: Jurnal Riset Ekonomi, Manajemen, Bisnis Dan Akuntansi, 5(3), 1383-1394. https://doi.org/https://doi.org/10.35794/emba.3.3.2015.10422

Mangkunegara, A. P. (2017). Manajemen Sumber Daya Manusia Perusabaan (14th ed.). Remaja 
Rosdakarya. https://opac.perpusnas.go.id/DetailOpac.aspx?id=243023

Mansur, Mattalatta, \& Baharuddin, D. (2017). Pengaruh Penempatan Kerja dan Stres Kerja Terhadap Kinerja Pegawai Pada Dinas Kependudukan Catatan Sipil Tenaga Kerja dan Transmigrasi Kabupaten Soppeng. Jurnal Mirai Management, 2(2), 338-358. https://doi.org/https://doi.org/10.37531/mirai.v2i2.61

Mathis, R. L., \& Jackson, J. H. (2016). Manajemen Sumber Daya Manusia (D. Angelica (ed.); 12th ed.). Salemba Empat. https://pustakaaceh.perpusnas.go.id/detail-opac?id=23371

McLarty, B. D., Muldoon, J., Quade, M., \& King, R. A. (2021). Your boss is the problem and solution: How supervisor-induced hindrance stressors and LMX influence employee job neglect and subsequent performance. Journal of Business Research, 130, 308-317. https://doi.org/10.1016/j.jbusres.2021.03.032

Miranto, A., Sulistiyanti, S. R., \& Arinto Setyawan, F. X. (2019). Adaptive Background Subtraction for Monitoring System. 2019 International Conference on Information and Communications Technology (ICOLACT), 153-156. https://doi.org/10.1109/ICOIACT46704.2019.8938501

Montolalu, R., Kawet, L., \& Nelwan, O. (2016). Pengaruh Kepribadian, Orientasi Kerja dan Penempatan Pegawai Terhadap Kinerja Pegawai Pada Dinas Kebudayaan dan Pariwsata Provinsi Sulawesi Utara. Jurnal EMBA: Jurnal Riset Ekonomi, Manajemen, Bisnis Dan Akuntansi, 4(1), 1318-1329. https://doi.org/https://doi.org/10.35794/emba.4.1.2016.12342

Moses, M. (2012). Analisis Pengaruh Pendidikan, Pelatihan, dan Pengalaman Kerja terhadap Produktivitas Kerja Pegawai Dinas Pertambangan dan Energi Provinsi Papua. Jurnal Media Riset Bisnis Dan Manajemen, 12(1), 18-36.

https://www.neliti.com/publications/52443/analisis-pengaruh-pendidikan-pelatihan-danpengalaman-kerja-terhadap-produktivit

Muvariz, F. R. (2019). Analisis Aspek Keadilan dari Pemberhentian Tidak Dengan Hormat Sebagai Pegawai Negeri Sipil di Indonesia. Jurnal Legislasi Indonesia, 16(2), 190-202. https://doi.org/https://doi.org/10.54629/jli.v16i2.446

Piwowar-Sulej, K. (2021). Human resources development as an element of sustainable HRM with the focus on production engineers. Journal of Cleaner Production, 278, 124008. https://doi.org/10.1016/j.jclepro.2020.124008

Silaban, S. M., \& Rifai, A. (2017). Analisis Kesesuaian Penempatan Pegawai Pada Dinas Kependudukan dan Pencatatan Sipil Kota Pekanbaru. Jurnal Administrasi Publik PUBLIKA, 3(1), 135-153. https://journal.uir.ac.id/index.php/JIAP/article/download/1742/1070

Situmorang, D. O., Marnisah, L., \& Zamzam, F. (2020). Pengaruh Pendidikan, Pelatihan, dan Penempatan Kerja Terhadap Kinerja Karyawan Division Operation 2 PT. Semen Baturaja (Persero) Tbk. Jurnal Media Wahana Ekonomika, 17(3), 242. https://doi.org/10.31851/jmwe.v17i3.4849

Sugiyono. (2019). Metode Penelitian Kuantitatif Kualitatif dan R\&D (I). Alfabeta. https://cvalfabeta.com/product/metode-penelitian-kuantitatif-kualitatif-dan-rd-mpkk/

Sulistiyani, A. T., \& Rosidah. (2013). Manajemen sumber daya manusia: konsep, teori dan pengembangan dalam konteks organisasi publik (2nd ed.). Graha Ilmu.

https:/ /opac.perpusnas.go.id/DetailOpac.aspx?id=410877

Sutrisno, E. (2013). Manajemen Sumber Daya Manusia (2nd ed.). Kencana Prenada Media. https://doi.org/https://doi.org/IOS3145.slims-16869 
Tamara, C. V.D., Johanes, A. W., Marlina, L., \& Hendra, K. A. (2021). Analisis Jabatan Dalam Penempatan Pegawai di Biro Pemerintahan dan Otonomi Daerah Sekretariat Provinsi Sulawesi Utara. Jurnal MSDA (Manajemen Sumber Daya Aparatur), 9(2), 128-141. https://doi.org/10.33701/jmsda.v9i2.2079

Tordera, N., Peiró, J. M., Ayala, Y., Villajos, E., \& Truxillo, D. (2020). The lagged influence of organizations' human resources practices on employees' career sustainability: The moderating role of age. Journal of Vocational Behavior, 120, 103444. https://doi.org/10.1016/j.jvb.2020.103444

Turere, V. N. (2013). Pengaruh Pendidikan dan Pelatihan Terhadap Peningkatan Kinerja Karyawan Pada Balai Pelatihan Teknis Pertanian Kalasey. Jurnal EMBA: Jurnal Riset Ekonomi, Manajemen, Bisnis Dan Akuntansi, 1(3), 10-19. https://doi.org/https://doi.org/10.35794/emba.1.3.2013.1368

Wicaksono, Y. S. (2016). Pengaruh Pelatihan dan Pengembangan Sumber Daya Manusia dalam Rangka Meningkatkan Semangat Kerja dan Kinerja Karyawan (Studi di SKM Unit V PT. Gudang Garam,Tbk Kediri). Jurnal Bisnis Dan Manajemen, 3(1), 31-39. https://doi.org/https://doi.org/10.26905/jbm.v3i1.71

Wirawan. (2015). Manajemen Sumber Daya Manusia Indonesia (1st ed.). RajaGrafindo Persada. https://www.rajagrafindo.co.id/produk/manajemen-sumber-daya-manusia-indonesia/

Yuliana, I., Djumadi, \& Paranoan, B. (2015). Penempatan Pegawai Dalam Meningkatkan Kinerja Di Lingkungan Kerja Badan Pengelolaan Keuangan Dan Aset Daerah Kota Samarinda. Jurnal Administrative Reform, 3(4), 428-440. https://doi.org/http://dx.doi.org/10.52239/jar.v3i4.582

Zhou, D. (2021). Role of green data center in human resources development model. Sustainable Computing: Informatics and Systems, 30, 100492. https://doi.org/10.1016/j.suscom.2020.100492 